\title{
Synthesis of New Pyrazolo [5, 1-c] [1, 2, 4] triazines from 5-Aminopyrazole and Study Biological Activity and Cytotoxicity
}

\author{
Wedad M. Al-Adiwish ${ }^{1,}$, , Maryam A. S. Abubakr², Naowara M. Alarafi ${ }^{3}$ \\ ${ }^{1}$ Chemistry Department, Faculty of Science, Azawia University, Az Zawiyah, Libya \\ ${ }^{2}$ Department of Botany, Faculty of Science, Azawia University, Az Zawiyah, Libya \\ ${ }^{3}$ Chemistry Department, Faculty of Science, Benghazi University, Benghazi, Libya
}

Email address:

wedad8073@yahoo.com (W. M. Al-Adiwish), maryam.abubaker@zu.edu.ly (M. A. S. Abubakr), Nourapro@gmail.com (N. M. Alarafi) ${ }^{*}$ Corresponding author

\section{To cite this article:}

Wedad M. Al-Adiwish, Maryam A. S. Abubakr, Naowara M. Alarafi. Synthesis of New Pyrazolo [5, 1-c] [1, 2, 4] triazines from 5Aminopyrazole and Study Biological Activity and Cytotoxicity. Cell Biology. Vol. 5, No. 5, 2017, pp. 45-52. doi: 10.11648/j.cb.20170505.11

Received: December 27, 2016; Accepted: January 9, 2017; Published: August 2, 2017

\begin{abstract}
Treatment of 2-[bis(methylthio)methylene]malononitrile 1 with $p$-Chloroaniline afforded 2-[(4chlorophenylamino) (methylthio) methylene] malononitrile 2a, of which upon reaction with hydrazine hydrate yielded 5amino-3-(4-chlorophenylamino)-1 $H$-pyrazole-4-carbonitrile 3 . This compound was utilized as a key intermediate for the synthesis of pyrazolo $[5,1-c][1,2,4]$ triazines by diazotization of 3 with nitrous acid at low temperature afforded 3-(4chlorophenylamino)-1H-pyrazole-4-carbonitrile-5-diazonium chloride $3^{\prime}$, in which coupling with active methylene of acetylacetone and malononitrile in the presence of pyridine gave the hydrazone derivatives, which cyclized directly upon addition of acetic acid to produce respective pyrazolo $[5,1-c][1,2,4]$ triazine derivatives 7 and 8 . Finally, treatment of 3 with acetic anhydride gave the acetyl amide derivative 9 . The antibacterial and antifungal activities, as well cytotoxicity against Breast cancer cells (MCF7) of some selected compounds are also reported.
\end{abstract}

Keywords: Pyrazolo $[5,1-c][1,2,4]$ triazines, $p$-Chloroaniline, 5-Aminopyrazole, Antibacterial Activity, Antifungal Activity, Cytotoxicity

\section{Introduction}

5-Aminopyrazoles have gained significant interest for synthetic organic chemists in the development of new biological active molecules of the pharmacological importance [1-5]. They have been used in the preparation of polyfunctionalized heterocyclic compounds such as pyrazolopyrimidines and pyrazolotriazines [6-9]. Various related compounds of pyrazolopyrimidines have antitumor and anti-leukemic activities [10,11]. On the other hand, substituted pyrazolotriazines are often used in medicine due to their pronounced bactericidal, fungicidal and antiviral effects [12, 13]. Cyclization of 5-aminopyrazoles with ketene- $S, S$ and $N$, $S$-acetals is the most widely used route for the synthesis of pyrazolotriazines [6-9]. Accordingly, we report in this paper synthesis of functionalized pyrazolo $[5,1-$ c] $[1,2,4]$ triazines 7 and 8 by the reactions of 5aminopyrazole 3 with respective acetylacetone and malononitrile. The antibacterial, antifungal, cytotoxicity testing results of two compounds is also included.

\section{Materials and Methods}

\subsection{Chemistry}

All melting points were determined using a hot stage Gallenkamp melting point apparatus. Infrared spectra were recorded from $\mathrm{KBr}$ discs on FT-IR 8300 Shimadzu spectrometer. ${ }^{1} \mathrm{H}$ NMR and ${ }^{13} \mathrm{C}$ NMR spectra were recorded on FT-NMR $400 \mathrm{MHz}$ Joel, ECP and FT-NMR $600 \mathrm{MHz}$ Bruker, AVANCE III spectrometer operating at $400 \mathrm{MHz}$, and $600 \mathrm{MHz}$ for ${ }^{1} \mathrm{H}$ NMR and at $100 \mathrm{MHz}, 150 \mathrm{MHz}$ for ${ }^{13} \mathrm{C}$ NMR in DMSO- $d_{6}$ as solvent and using TMS as 
internal standard. DIMS spectra were recorded on QP5050A Shimadzu apparatus. X-ray diffraction (XR-D) data were collected at room temperature with Bruker APEXII CCD a spectrometer. General purpose silica gel of Merck No. 5545 with UV indicator were used in TLC experiments to monitor completion of reactions, in which DCM was used as eluent.

\subsubsection{Synthesis of 2-I(4-Chloropzhenylamino) (Methylthio) Methylene] Malononitrile (2a)}

A mixture of 2-[bis (methylthio) methylene] malononitril 1 (1.7 g, $0.01 \mathrm{~mol}), p$-chloroaniline $(1.27 \mathrm{~g}, 0.01 \mathrm{~mol})$, and three drops of triethylamine (TEA) was refluxed in absolute ethanol $30 \mathrm{~mL}$ on oil-bath in the presence balloon of nitrogen. The reaction mixture was refluxed for one week. The solvent was evaporated and the product was collected, washed with ethanol, dried and recrystallized from ethanol to give pure 2-[(4-chlorophenylamino) (methylthio) methylene] malononitrile $2 \mathrm{a}$.

Yield, 48\%; colorless crystals; mp $165-167^{\circ} \mathrm{C}$; FT-IR $\left(\mathrm{KBr}, \mathrm{cm}^{-1}\right) v: 3246(\mathrm{NH}-\mathrm{Ar}), 3010(\mathrm{H}-\mathrm{Ar}), 2200,2189$ $(2 \mathrm{CN}), 1585,1526,1500(\mathrm{C}=\mathrm{C} / \mathrm{C}=\mathrm{N}) ;{ }^{1} \mathrm{H}$ NMR $(400 \mathrm{MHz}$, DMSO-d $d_{6} \delta: 2.50\left(\mathrm{~s}, 3 \mathrm{H}, \mathrm{SCH}_{3}\right), 7.34(\mathrm{~d}, 2 \mathrm{H}, 2 \mathrm{H}-\mathrm{Ar}$, $J=8.04), 7.49$ (d, 2H, 2H-Ar, $J=8.04), 10.58$ (s, 1H, NH-Ar); ${ }^{13} \mathrm{C}$ NMR (100 MHz, DMSO- $\left.d_{6}\right) \delta: 16.4\left(\mathrm{SCH}_{3}\right), 53.9$ $(\mathrm{C}-2 \mathrm{CN}), 116.9(2 \mathrm{CN}), 126.2(2 \mathrm{C}-\mathrm{H}, \mathrm{Ar}), 129.7(2 \mathrm{C}-\mathrm{H}$, Ar), $131.2(\mathrm{C}-\mathrm{Cl}), 137.9$ (C-NH, Ar), 172.4 (S-C-NH).

\subsubsection{General Procedure for the Synthesis of 5-amino-3-(4- Chlorophenylamino)-1H-Pyrazole-4-Carbonitrile (3)}

A mixture of 2-[(4-chlorophenylamino) (methylthio) methylene] malononitrile 2a $(0.998,4 \mathrm{mmol})$ and hydrazine hydrate $(1.00 \mathrm{~g}, 20 \mathrm{mmol})$ was refluxed on water-bath for 2 hours. Then, $20 \mathrm{~mL}$ of ethanol was added, and the reaction mixture was refluxed for further 2 hours. The solvent was evaporated and the product was collected, washed with ethanol, dried and recrystallized from methanol to give pure product 3.

Yield, 97\%; whit solid; mp 240-242 $\mathrm{C}$; FT-IR $\left(\mathrm{KBr}, \mathrm{cm}^{-1}\right)$ v: 3430, $3254\left(\mathrm{NH}_{2} / \mathrm{NH}-\mathrm{Ar}\right), 2915(\mathrm{H}-\mathrm{Ar}), 2212(\mathrm{CN})$, 1622, 1611, $1584(\mathrm{C}=\mathrm{C} / \mathrm{C}=\mathrm{N})$; ${ }^{1} \mathrm{H}$ NMR (400 MHz, DMSO$\left.d_{6}\right) \delta: 6.30\left(\mathrm{~s}, 2 \mathrm{H}, \mathrm{NH}_{2}\right.$, pyrazole), $7.20(\mathrm{~d}, 2 \mathrm{H}, 2 \mathrm{H}-\mathrm{Ar}, J=8.8$ $\mathrm{Hz}), 7.50$ (d, 2H, 2H-Ar, J=8.8 Hz), $8.54(\mathrm{~s}, 1 \mathrm{H}, \mathrm{NH}$, pyrazole), 11.19 (s, 1H, NH-Ar); ${ }^{13} \mathrm{C}$ NMR (100 MHz, DMSO- $\left.d_{6}\right) \delta: 63.6(\mathrm{C}-\mathrm{CN}), 115.7(\mathrm{CN}), 118.2(2 \mathrm{C}=\mathrm{H}, \mathrm{Ar})$, $122.9(\mathrm{C}-\mathrm{Cl}), 128.8(2 \mathrm{C}=\mathrm{H}, \mathrm{Ar}), 142.2(\mathrm{C}-\mathrm{NH}, \mathrm{Ar}), 151.2$ $(\mathrm{NH}-\mathrm{C}-\mathrm{N}), 153.5\left(\mathrm{C}-\mathrm{NH}_{2}\right)$.

\subsubsection{General Procedure for the Preparation of Pyrazolo [5, 1-c] [1, 2, 4] Triazines 4 and 5}

To a solution each of acetyl acetone $(0.20 \mathrm{~g} ; 2 \mathrm{mmoL})$ or malononitrile $(0.13 \mathrm{~g} ; 2 \mathrm{mmoL})$ in pyridine $(5 \mathrm{~mL})$, an icecooled solution of the appropriate diazonium solution [prepared by the addition of a solution of sodium nitrite $(0.138 \mathrm{~g} ; 2 \mathrm{mmol})$ in water $(2 \mathrm{~mL})$ to the required 5aminopyrazole $3(0.467 \mathrm{~g} ; 2 \mathrm{mmol})$ in hydrochloric acid and acetic anhydride [(2:8) $10 \mathrm{~mL}(1 / 4)$ vol.] was added drop wise with stirring. Stirring was maintained for overnight.
Each the precipitated product was filtered, washed with water, dried and crystallized from EtOH-DMF (2:2) afforded compounds 7 and 8 .

i. 3-acetyl-7-(4-chlorophenylamino)-4-methylpyrazolo [5, 1-c] [1, 2, 4] triazine-8-carbonitrile (4)

Yield, 60\%; brown solid; mp $269^{\circ} \mathrm{C}$ decomposed; IR (KBr, $\left.\mathrm{cm}^{-1}\right) v: 3302(\mathrm{NH}), 2234(\mathrm{CN}), 1696(\mathrm{C}=\mathrm{O}), 1629,1585$, $1566(\mathrm{C}=\mathrm{C} / \mathrm{N}=\mathrm{N} / \mathrm{C}=\mathrm{N}) ;{ }^{1} \mathrm{H}$ NMR $\left(600 \mathrm{MHz}, \mathrm{DMSO}-d_{6}\right) \delta$ : $2.82\left(\mathrm{~s}, 3 \mathrm{H}, \mathrm{C}=\mathrm{C}-\mathrm{CH}_{3}\right), 3.02\left(\mathrm{~s}, 3 \mathrm{H}, \mathrm{CO}-\mathrm{CH}_{3}\right), 7.43(\mathrm{~d}, 2 \mathrm{H}$, $2 \mathrm{CH}=, \mathrm{Ar}, J=9.0 \mathrm{~Hz}), 7.80(\mathrm{~d}, 2 \mathrm{H}, 2 \mathrm{CH}=, \mathrm{Ar}, J=9.0 \mathrm{~Hz})$, 10.36 (s, 1H, NH, Ar); ${ }^{13} \mathrm{C}$ NMR (150 MHz, DMSO-d 6 ) $\delta$ : $14.02\left(\mathrm{C}=\mathrm{C}-\mathrm{CH}_{3}\right), 28.9\left(\mathrm{CO}-\mathrm{CH}_{3}\right), 69.1(\mathrm{C}-\mathrm{CN}), 112.5$ $(\mathrm{CN}), 121.1(2 \mathrm{CH}=, \mathrm{Ar}), 126.9(=\mathrm{C}-\mathrm{Cl}, \mathrm{Ar}), 138.9(\mathrm{C}-\mathrm{NH})$, $139.8(\mathrm{C}-\mathrm{N}=\mathrm{N}), 142.2(\mathrm{C}-\mathrm{CO}), 151.1(\mathrm{HN}-\mathrm{C}=\mathrm{N}), 158.1$ $\left(\mathrm{C}-\mathrm{CH}_{3}\right), 198.4(\mathrm{C}=\mathrm{O})$; DIMS found $\mathrm{m} / \mathrm{z}$ : 326.75 (calc. for $\mathrm{C}_{15} \mathrm{H}_{11} \mathrm{ClN}_{6} \mathrm{O} \mathrm{M}^{+}$requires: 326.74).

ii. 4-amino-7-(4-chlorophenylamino) pyrazolo [5, 1-c] [1, 2, 4] triazine-3, 8-dicarbonitrile (5)

Yield, $75 \%$; yellow crystals; $\mathrm{mp}>336^{\circ} \mathrm{C}$; IR $\left(\mathrm{KBr}, \mathrm{cm}^{-1}\right)$ v: $3294(\mathrm{NH}), 3089(\mathrm{CH}-\mathrm{Ar}), 2809$ (CH, aliphatic), 2228 $(\mathrm{CN}), 1639,1583(\mathrm{C}=\mathrm{C} / \mathrm{N}=\mathrm{N} / \mathrm{C}=\mathrm{N}) ;{ }^{1} \mathrm{H} \mathrm{NMR}(600 \mathrm{MHz}$, DMSO- $\left.d_{6}\right) \delta: 2.73\left(\mathrm{~s}, 3 \mathrm{H}, \mathrm{N}-\mathrm{CH}_{3}, \mathrm{DMF}\right), 2.89$ (s, 3H, $\left.\mathrm{N}-\mathrm{CH}_{3}, \mathrm{DMF}\right), 7.32$ (d, 2H, 2CH=, Ar, $J=15.0 \mathrm{~Hz}$ ), 7.94 (s, 1H, CH, DMF), 7.98 (d, 2H, 2CH=, Ar, J=15.0 Hz), 9.48 (br, $\left.2 \mathrm{H}, \mathrm{NH}_{2}\right), 9.97(\mathrm{~s}, 1 \mathrm{H}, \mathrm{NH}, \mathrm{Ar}) ;{ }^{13} \mathrm{C} \mathrm{NMR}(150 \mathrm{MHz}$, DMSO-d 6 ) $\delta: 31.2\left(\mathrm{~N}-\mathrm{CH}_{3}, \mathrm{DMF}\right), 36.3\left(\mathrm{~N}-\mathrm{CH}_{3}, \mathrm{DMF}\right), 69.6$ $(\mathrm{C}-\mathrm{CN}), 111.1(\mathrm{C}-\mathrm{CN}), 112.8(\mathrm{CN}), 115.4(\mathrm{CN}), 120.5$ (2CH=, Ar), 125.7 (=C-Cl, Ar), $128.9(2 \mathrm{CH}=, \mathrm{Ar}), 139.4$ $(\mathrm{C}-\mathrm{NH}), \quad 141.9 \quad(\mathrm{C}-\mathrm{N}=\mathrm{N}), \quad 150.7 \quad\left(\mathrm{C}-\mathrm{NH}_{2}\right), \quad 156.2$ $(\mathrm{HN}-\mathrm{C}=\mathrm{N}), 162.8(\mathrm{H}-\mathrm{C}=\mathrm{O}, \mathrm{DMF})$; DIMS found $m / z: 310.10$ (calc. for $\mathrm{C}_{13} \mathrm{H}_{7} \mathrm{ClN}_{8} \mathrm{M}^{+}$requires: 310.05 ).

\subsubsection{General Procedure the Preparation of 1-Acetyl-5- Amino-3-(4-Chlorophenylamino)-1H-Pyrazole-4- Carbonitrile (6)}

These were prepared according to the literature procedure [14] as follows: A solution of 5-aminopyrazole 3 (2 mmol) in acetic anhydride $(10 \mathrm{~mL})$ was heated under reflux for $15 \mathrm{~min}$. The solid products so formed was collected by filtration and recrystallized from DMF:EtOH to give product 9 .

Yield, 84\%; whit solid; mp 295-296 ${ }^{\circ} \mathrm{C}$; IR $\left(\mathrm{KBr}, \mathrm{cm}^{-1}\right) v$ : 3416, $3263\left(\mathrm{NH} / \mathrm{NH}_{2}\right), 2211(\mathrm{CN}), 1703$ (CO), 1602 $(\mathrm{C}=\mathrm{C} / \mathrm{C}=\mathrm{N}) ;{ }^{1} \mathrm{H}$ NMR (600 MHz, DMSO) $\delta: 2.56(\mathrm{~s}, 3 \mathrm{H}$, $\left.\mathrm{CH}_{3}-\mathrm{CO}\right), 7.31$ (d, 2H, 2CH=Ar), 7.69 (d, 2H, 2CH=Ar), $8.00\left(\mathrm{~s}, 2 \mathrm{H}, \mathrm{NH}_{2}\right), 9.10(\mathrm{~s}, 1 \mathrm{H}, \mathrm{NH}) ;{ }^{13} \mathrm{C} \mathrm{NMR}(150 \mathrm{MHz}$, DMSO) $\delta: 23.8\left(\mathrm{CH}_{3}-\mathrm{CO}\right), 64.7(\mathrm{C}-\mathrm{CN}), 113.7(\mathrm{CN}), 119.6$ $(2 \mathrm{H}, 2 \mathrm{CH}=, \mathrm{Ar}, J=13.2 \mathrm{~Hz}), 124.7(\mathrm{H}, \mathrm{Cl}-\mathrm{C}=, \mathrm{Ar}), 128.9$ $(2 \mathrm{H}, \quad 2 \mathrm{CH}=, \quad$ Ar, $J=13.2 \mathrm{~Hz}), 140.4(\mathrm{C}-\mathrm{N}-\mathrm{H}), 151.0$ $(\mathrm{NH}-\mathrm{C}=\mathrm{N}), 155.2\left(\mathrm{C}-\mathrm{NH}_{2}\right), 172.9(\mathrm{C}=\mathrm{O})$; DIMS found $\mathrm{m} / \mathrm{z}$ : 275.65 (calc. for $\mathrm{C}_{12} \mathrm{H}_{10} \mathrm{ClN}_{5} \mathrm{O} \mathrm{M}$ requires 275.69).

\subsection{Antibacterial and Antifungal Evaluations}

The synthesized compounds were evaluated for their antibacterial and antifungal activities using the agar diffusion technique [15] to determine which antibiotic (sample given) are most successful in treating bacteria or fungal infections. The response (sensitivity/resistance) of microbes against 
antimicrobial compounds various to each other. Microbes used in this test are: three bacterial [Staphylococcus aureus S276, Staphylococcus epidermidis S276, and Pseudomonas aeruginosa 15442] and two fungi: [Aspergillusbrasiliensis ATCC 1640 and Aspergillusniger UPMC 393]. The test is carried out by placing $6 \mathrm{~mm}$ diameter of paper disc containing antibiotic onto a plate which microbes are growing. The microbe culture is standardized to 0.5 McFarland standards which is approximately $10^{8}$ cells. Not more than 6 discs should be placed on the same agar plate. Streptomycin standard are used for each bacteria and Nystatin standard are used for fungi. The plates are inverted and incubate at $30-37^{\circ} \mathrm{C}$ for $18-24$ hours, $24-48$ or until sufficient growth has occurred. After incubation, each plate is examined. The diameters of the zones of complete inhibition (as judged by the unaided eye) are measured, including the diameter of the disc. Zones are measured to the nearest whole millimeter, using sliding calipers or a ruler, which is held on the back of the inverted Petri plate.

\subsection{Cytotoxicity Assay}

Some of the selected synthesized compounds were also tested against human breast adenocarcinoma (MCF-7) cell lines by using the MTT assay. Human MCF-7 breast adenocarcinoma cell line was procured from ATCC. The cells were cultured in a humid environment at $37^{\circ} \mathrm{C}$ and $5 \%$ $\mathrm{CO}_{2}$ as a monolayer in DMEM (Dulbecco's Modified Eagles Medium; US Biological) supplemented with 10\% FBS (Fetal Bovine Serum; Bioclot) and $1 \%$ penicillin/streptomycin (Invitrogen). Cells were grown up to $85-90 \%$ confluence and harvested using $0.25 \%$ trypsin/EDTA solution before subcultured onto 96-well plates. Cells were then treated with different compounds at a final concentration ranging from $0.47-30 \mu \mathrm{g} / \mathrm{mL}$ for $24 \mathrm{hrs}$. Stock solutions were prepared in dimethylsulfoxide (DMSO) and stored at $20^{\circ} \mathrm{C}$ until used. The 3-(4, 5-dimethylthiazol-2-yl)-2, 5-diphenyl tetrazolium bromide (MTT) colorimetric assay developed [16] with modification was used to screen the cytotoxic activity of compounds. Briefly, $100 \mu$ l of the MCF-7 cells ( 1 x 105 cells $/ \mathrm{mL}$ ) were subculture onto sterile flat-bottomed 96 well plates and exposed to 7 different concentrations (30.00, $15.00,7.50,3.75,1.87,0.93$ and $0.47 \mu \mathrm{g} / \mathrm{mL}$ ) of each compound for $24 \mathrm{~h}$. After the completion of Incubation in $37^{\circ} \mathrm{C}, 5 \% \mathrm{CO}_{2}$ incubator, $20 \mu \mathrm{L}$ of MTT reagent (Invitrogen) in $5.0 \mathrm{mg} / \mathrm{mL}$ phosphate buffered saline (PBS) was added to each well and further incubated for $3 \mathrm{~h}$ at $37^{\circ} \mathrm{C}, 5 \% \mathrm{CO}_{2}$ incubator. MTT solution was then removed before $100 \mu \mathrm{L}$ of DMSO (Sigma Aldrich) were added to each well and mix thoroughly to dissolve the blue formazan crystals. Further incubation was carried out for $20 \mathrm{~min}$. Finally, the optical density (OD) of each well was measured on ELISA reader at $570 \mathrm{~nm}$ (test wavelength) and $630 \mathrm{~nm}$ (reference wavelength). This cytotoxixity test was performed in two independent experiments, each time in triplicate. The percentage of cytotoxicity compared to the untreated cells was determined. The percentage of viability against each compound concentration were plotted to determine the $\mathrm{CC}_{50}$ value (the concentration at which $50 \%$ cell proliferation is inhibited).

The percentage of cells viability was calculated in relative with the number of viable cells as a percentage of control by defining the absorbance at $570 \mathrm{~nm}$ for the control as $100 \%$.

\section{Results and Discussions}

\subsection{Chemistry}

The 5-amino-3-[4-chlorophenylamino]-1H-pyrazole-4carbonitrile intermediate 3 was prepared from cyclocondensation of respective $\alpha, \alpha$-dicyanoketene- $N, S$ acetal 2-[(4-chlorophenylamino) (methylthio) methylene] malononitrile $2 \mathrm{a}$ with hydrazine hydrate under reflux in ethanol for four hours (figure 1). The starting material 2a was prepared via the reaction of 2-[bis (methylthio) methylene] malononitrile 1 with an aromatic amine of $p$-choroaniline under reflux in ethanol in the presence of balloon of nitrogen gas for one week.<smiles>CC(C)=C(C#N)C#N</smiles><smiles>CCOC(C)(C)c1ccc(Nc2ccc(Cl)cc2)cc1</smiles><smiles></smiles>

Figure 1. Synthesis of 5-aminopyrazole 3.

The possible formation of the 5-aminopyrazole 3 is shown in figure 2. First, Michael addition to 2-[(4chlorophenylamino) (methylthio) methylene] malononitrile 2a occurs with a lone pair of the $\mathrm{NH}_{2}$ group in hydrazine to form an intermediate adduct $\mathrm{A}$. Then, the methylthio anion is removed, which results in the formation of intermediate B. This methylthio anion abstracts a proton of the ammonium ion to produce an intermediate C. Subsequently, intermolecular cyclization occurs by a lone pair on the remaining $\mathrm{NH}_{2}$ group attacking the carbon on cyano group to produce intermediate $\mathrm{D}$. The ammonium proton intramolecular abstraction in D occurs (1, 3-hydrogen migration) to form $\mathrm{E}$, followed by aromatic-driven 1, 5hydrogen migration to yield product 3 . 


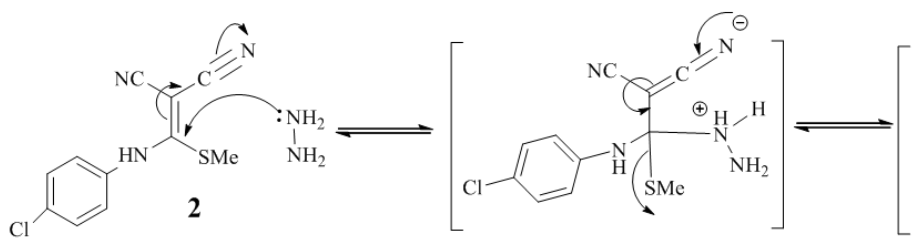

A

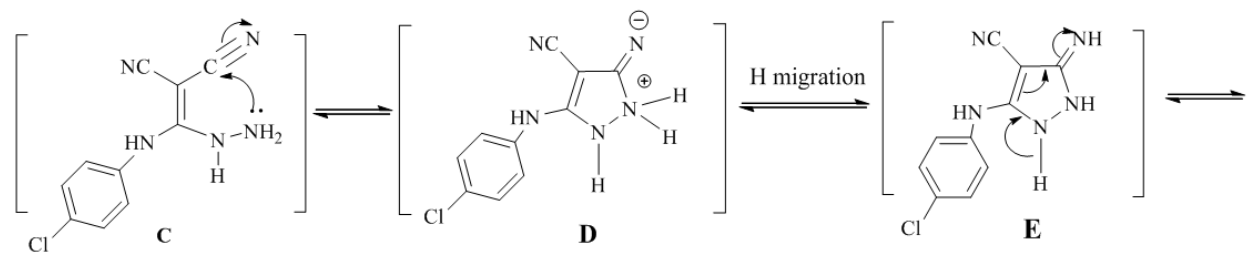<smiles>N#Cc1c(Nc2ccc(Cl)cc2)n[nH]c1N</smiles>

Figure 2. Mechanism for formation of 5-aminopyrazole 3.

The chemical structure of the compound 3 was established on the basis of its spectral data. IR spectrum of 3 showed bands at $v 3430,3254 \mathrm{~cm}^{-1}$ for $\mathrm{NH}$ and $\mathrm{NH}_{2}$ groups. The $\mathrm{NH}_{2}$ protons in ${ }^{1} \mathrm{H}$ NMR spectrum were at $\delta 6.30 \mathrm{ppm}$, whereas the two singlet signals at $\delta 8.54$ and $11.19 \mathrm{ppm}$ assignable to the respective ArNH and cyclo-NH protons. The ${ }^{13} \mathrm{C}$ NMR spectrum was characterized by signals at $\delta 151.2$ and 153.5 ppm assigned to respective aromatic carbons of $\mathrm{NH}-\mathrm{C}=\mathrm{N}$ and $\mathrm{C}-\mathrm{NH}_{2}$. In addition, signals between $\delta 118.2-142.2 \mathrm{ppm}$ assigned to the other carbons of aromatic rings.

The structure of compound 2a was identified by X-ray diffraction analysis. The molecular structure and the numbering scheme of $2 \mathrm{a}$ are presented in Figure 3. Suitable crystals of $2 \mathrm{a}$ were grown by slow evaporation from $\mathrm{MeOH}$ solution after 48 hours. The crystal data and structure refinement results for $2 \mathrm{a}$ are given in Table 1. Compound $2 \mathrm{a}$ crystallized in a monoclinic system with space group of $P 21 / n$. Some selected bond distances and bond angles for $2 \mathrm{a}$ are given in Table 2. The bond lengths and angles of the molecule are within in the normal ranges [17]. The phenyl ring, (C1-C6), in compound 2a is essentially planar with a maximum deviation of 0.000 (17) $\AA$, for atom $\mathrm{C} 2$. The $\mathrm{N} 2 / \mathrm{N} 3 / \mathrm{C} 8 / \mathrm{C} 9 / \mathrm{C} 10$ fragment is essentially planar with a maximum deviation of 0.000 (12) $\AA$, for atom C8, and the dihedral angle between the mean plane and the phenyl ring is $69.8(9)^{\circ}$ (see Electronic Supplementary Information [18]). In crystal packing of compound 2a, the molecules are connected by weak $\mathrm{C}-\mathrm{H}^{\cdots \cdots} \mathrm{N}$ and $\mathrm{N}-\mathrm{H}^{\cdots} \mathrm{N}$ intermolecular hydrogen bonds forming one-dimensional chains along the $b$ axis (Figure 4).

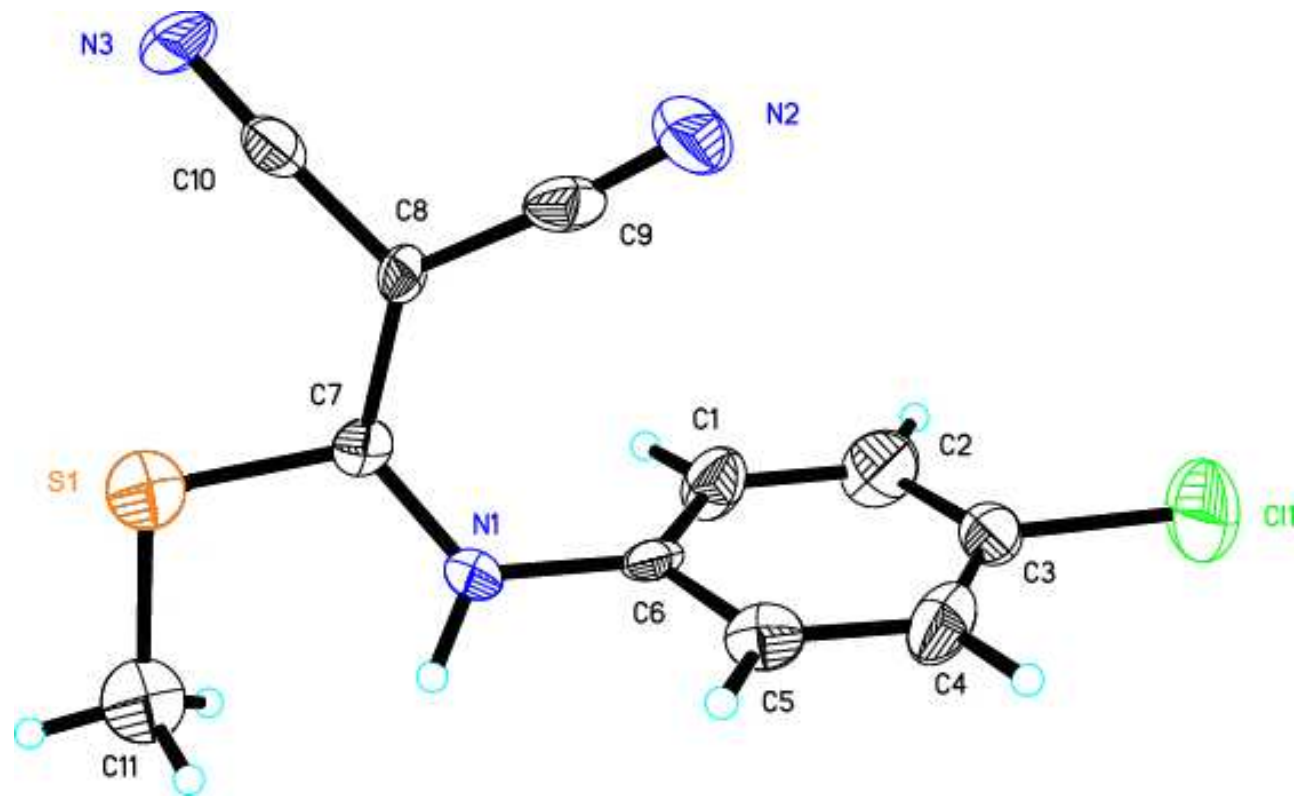

Figure 3. The molecular structure of 2 a with $50 \%$ probability displacement ellipsoids. 


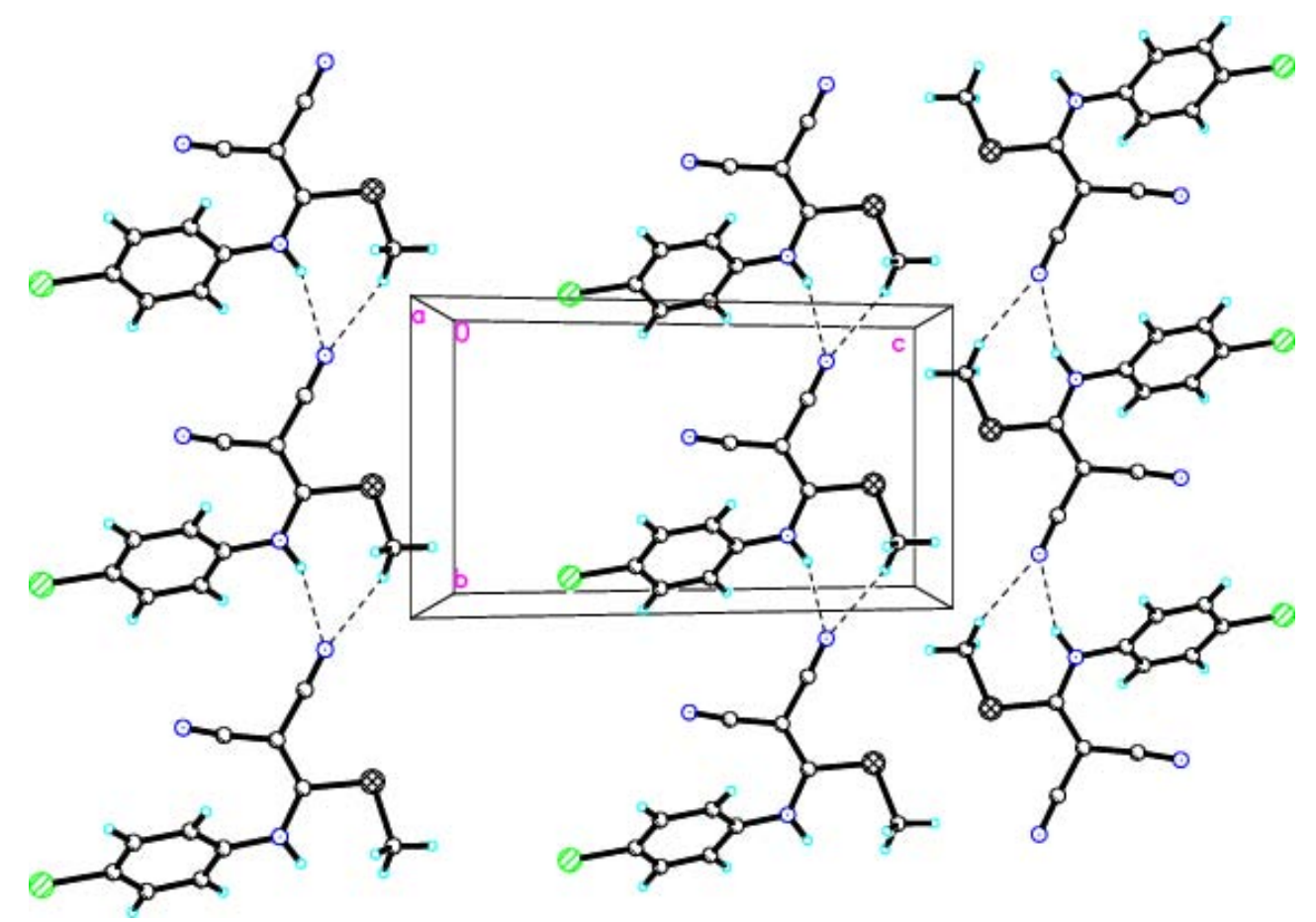

Figure 4. Packing diagrams of compound $2 a$, viewed down the b axis. The dashed lines denote $C-H \cdots N$ and $N-H \cdots N$ hydrogen bonds.

Table 1. Crystal data and structure refinement for $2 a$.

\begin{tabular}{llll}
\hline & Crystal 2a & & Crystal 2a \\
\hline Chemical formula & $\mathrm{C}_{11} \mathrm{H}_{8} \mathrm{Cl} \mathrm{N}_{3} \mathrm{~S}$ & Absorption coefficient & $0.268 \mathrm{~mm}^{-1}$ \\
Formula weight & $249.72 \mathrm{~g} \mathrm{~mol}^{-1}$ & $\mathrm{~F}(000)$ & 512 \\
Colour & Yellowish & Theta range for data collection & $3.2-28.3\left(^{\circ}\right)$ \\
Crystal shape & Block & Reflections collected / unique & $17124,2684, R_{\text {int }}=0.077$ \\
Size mm & $0.31 \times 0.25 \times 0.35$ & Completeness to theta $=25.00$ & 71.025 \\
Temperature & $293 \mathrm{~K}$ & Max. and min. transmission & $T_{\min }=0.923, T_{\max }=0.939$ \\
Wavelength & $0.71073 \AA$ & Refinement method & Full-matrix least-squares on $\mathrm{F}^{2}$ \\
Crystal system & Monoclinic & Data/ restraints/ parameters & $3322 / 0 / 253$ \\
Space group & $P 21 / n$ & Goodness-of-fit on $\mathrm{F}^{2}$ & 1.36 Full-matrix least-squares on $\mathrm{F}^{2}$ \\
& $12.2861(9)$ & & \\
$a, b, c(\AA) ;$ & $7.4046(5)$ & Final R indices [I $22 \sigma(\mathrm{I})]$ & $R=0.2808, w R=0.5367$ \\
& $13.6025(9)$ & & \\
$\alpha, \beta, \gamma()^{\circ}$ & $90,109.282(3), 90$ & Largest diff. peak and hole & $-1.64, \& 2.48 \mathrm{e} \AA^{-3}$ \\
Cell volume & $1168.05(14)$ & Calculated density & $1.4393(2) \mathrm{g} . \mathrm{cm}^{-3}$ \\
$\mathrm{Z}$ & 4 & & \\
\hline
\end{tabular}

Table 2. Selected bond lengths ( $(\AA)$ and bond angles $\left(^{\circ}\right)$ for $2 a$.

\begin{tabular}{llll}
\hline Bond & Bond length $(\AA)$ & Bond & Bond angle $\left(^{\circ}\right)$ \\
\hline C11-C1 & $1.737(15)$ & C7-S1-C11 & $104.5(7)$ \\
S1-C7 & $1.741(12)$ & C4-N1-C7 & $126.8(11)$ \\
S1-C11 & $1.748(15)$ & C11-C1-C2 & $118.3(13)$ \\
N1-C4 & $1.435(17)$ & N1-C4-C3 & $120.0(13)$ \\
N1-C7 & $1.333(16)$ & S1-C7-N1 & $119.8(9)$ \\
N2-C9 & $1.133(19)$ & N1-C7-C8 & $125.3(11)$ \\
N3-C10 & $1.13(2)$ & S1-C7-C8 & $114.9(9)$ \\
C7-C8 & $1.386(16)$ & C7-C8-C9 & $121.3(11)$ \\
C8-C9 & $1.429(19)$ & C7-C8-C10 & $125.3(11)$ \\
C8-C10 & $1.443(19)$ & C9-C8-C10 & $112.8(11)$ \\
\hline
\end{tabular}

The above mentioned 5-aminopyrazole 3 was used as intermediates for the synthesis of pyrazolo $[5,1-c][1,2,4]$ triazines, on other hand the diazotized of 5-aminopyrazoles is an excellent building block for the synthesis of the pyrazolo $[5,1-c][1,2,4]$ triazine derivatives $[19,20]$. Thus, diazotization of 5-aminopyrazole 3 with sodium nitrite and conc. $\mathrm{HCl}$ gave the corresponding 3-(4-chlorophenylamino)1H-pyrazole-4-carbonitrile-5-diazonium chloride 3', which was coupled with different active methylene compounds, namely; acetylacetone and malononitrile in pyridine to afford the corresponding hydrazono derivatives $\mathrm{A}$ and $\mathrm{B}$, respectively. When the intermediates $\mathrm{A}$ and $\mathrm{B}$ were refluxed in glacial acetic acid, the target 3-acetyl-7-(4chlorophenylamino)-4-methylpyrazolo $[5,1-c] \quad[1,2,4]$ triazine-8-carbonitrile 4 and 4-amino-7-(4chlorophenylamino) pyrazolo $[5,1-c][1,2,4]$ triazine-3, 8 dicarbonitrile 5 were obtained. The formation of 4 and 5 may be interpreted through the nuclophilic attack of ring nitrogen on acetyl or cyano groups (Figure 5). 


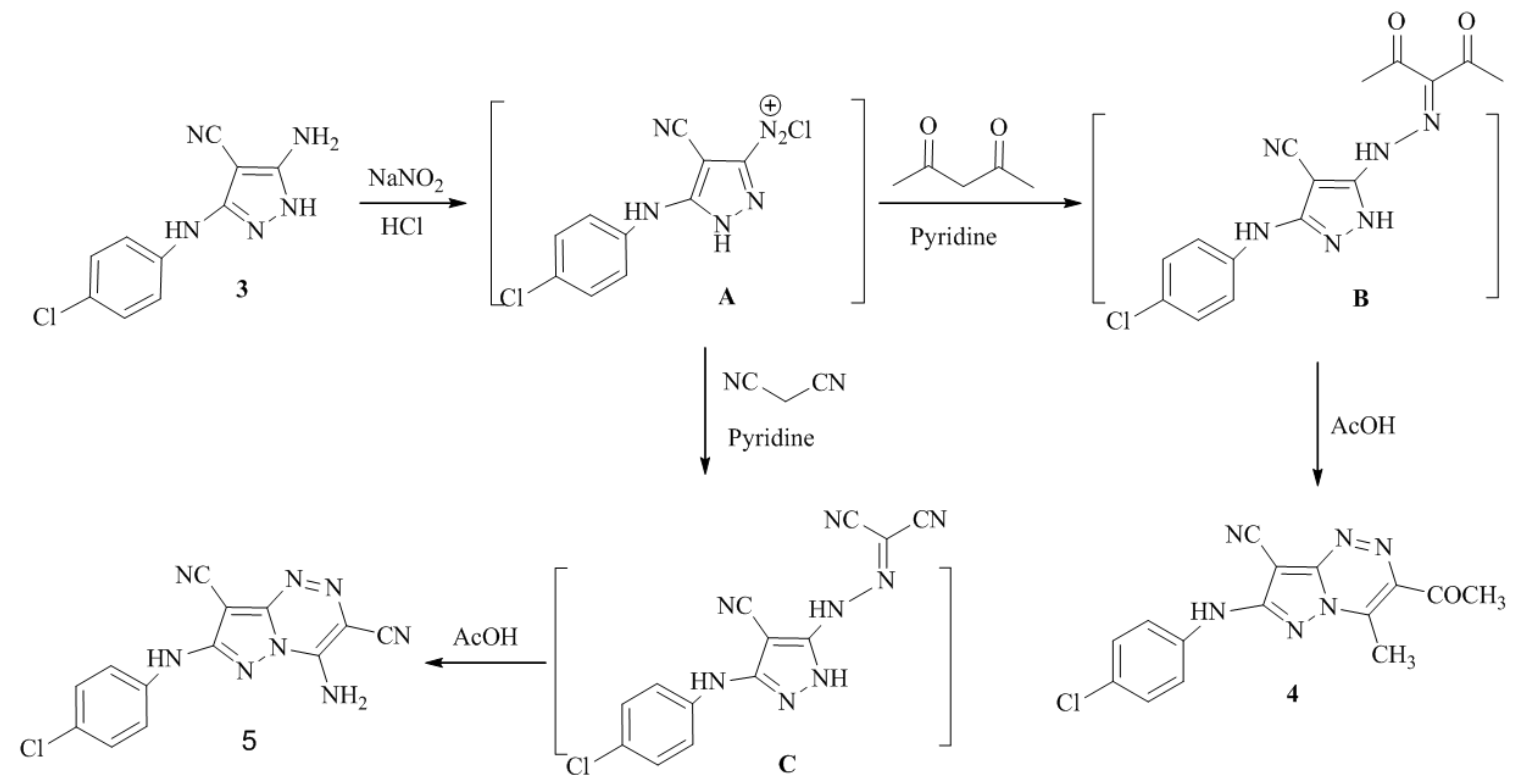

Figure 5. Synthesis of pyrazolo $[5,1-c][1,2,4]$ triazines 4 and 5.

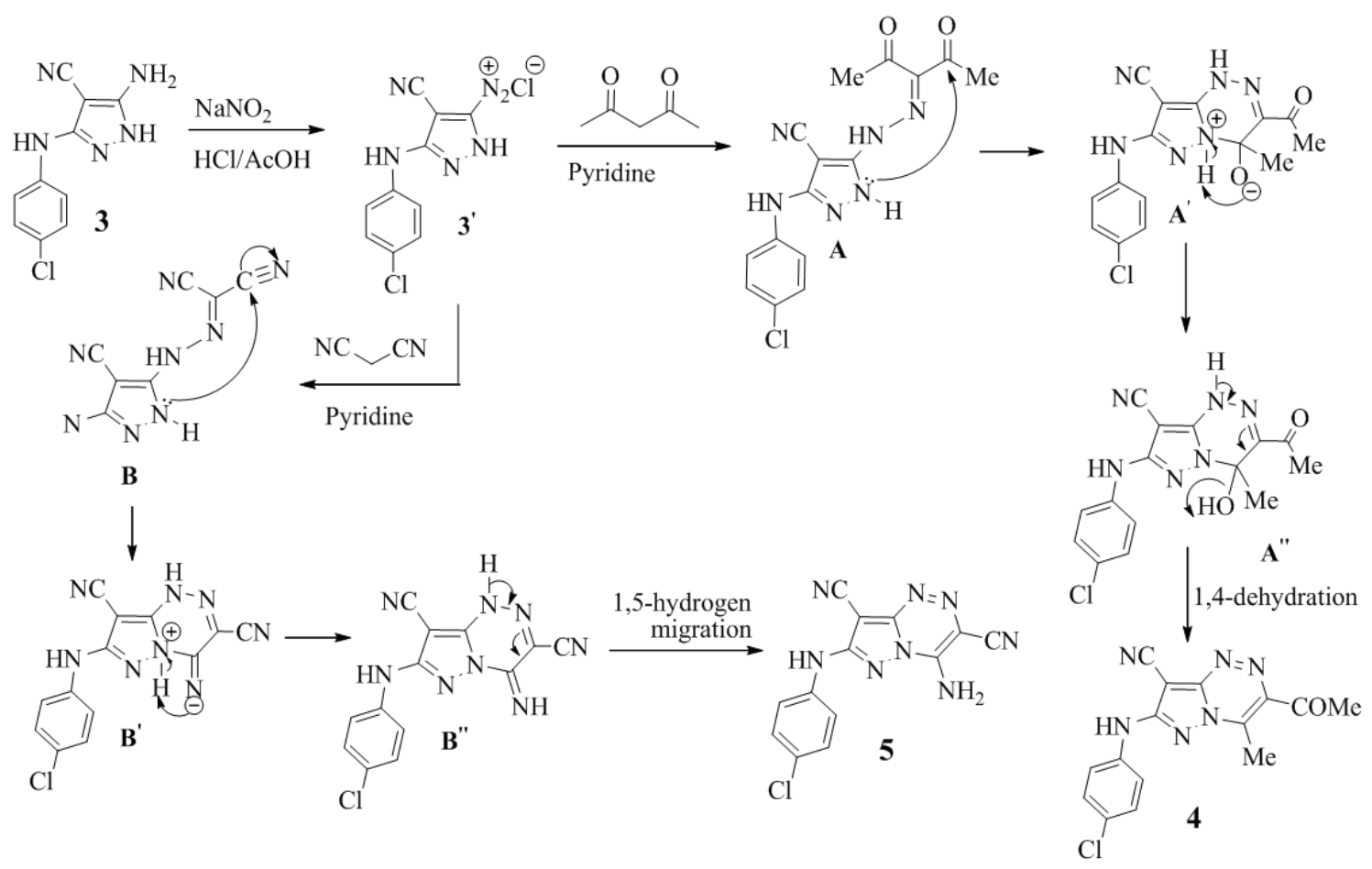

Figure 6. Mechanism for formation of pyrazolo [5, 1-c] [1, 2, 4] triazines 4 and 5 .

The structures of 4 and 5 were elucidated on the basis of spectral data. The characteristic absorption band in the IR spectra of 4 and 5 is at $v 1583-1585 \mathrm{~cm}^{-1}$ for $\mathrm{N}=\mathrm{N}$ stretching vibrations. Furthermore, displayed band at $v 1696 \mathrm{~cm}^{-1}$ in the compound 4 revealed to the carbonyl group and the $\mathrm{NH}_{2}$ group in the compound 5 disappeared in the IR spectrum due to formation of hydrogen bonding with DMF, which used as solvent to purification of compound 5 and appeared only band at $3293 \mathrm{~cm}^{-1}$ for NH group. The ${ }^{1} \mathrm{H}$ NMR spectra of the compound 4 displayed broad signals at $\delta$ 2.82-3.02 ppm, which corresponding to six protons of two methyl groups. The ${ }^{1} \mathrm{H}$ NMR spectra of the compound 8 displayed broad signal at $\delta 9.97 \mathrm{ppm}$ due to $\mathrm{NH}$ group attached to aromatic ring. While the signal at $\delta 9.48 \mathrm{ppm}$ due to $\mathrm{NH}_{2}$ group, which form the hydrogen bonding with oxygen of DMF. The structures of the isolated products 4 and 5 were supported by their direct infusion mass spectrometry (DIMS) results, which showed molecular ions corresponding to the molecular formula. The DIMS of compound 4 showed a molecular ion at $m / z=326.75$ which corresponds to the molecular formula 
$\mathrm{C}_{15} \mathrm{H}_{11} \mathrm{ClN}_{6} \mathrm{O}$ (326.74). The DIMS of compound 5 showed a molecular ion at $m / z=310.10$ which correspond to the molecular formula $\mathrm{C}_{13} \mathrm{H}_{7} \mathrm{ClN}_{8} \mathrm{M}^{+}$requires 310.05 . The molecular ion at $m / z=73.10$ which correspond to the molecular formula of DMF $\mathrm{C}_{3} \mathrm{H}_{7} \mathrm{NO} \mathrm{M}{ }^{+}$requires 73.07.

The mechanism for the formation of pyrazolo $[5,1-c][1$, $2,4]$ triazines 4 and 5 is presented in Figure 6 . The first step involves the formation of 3-(4-chlorophenylamino)- $1 \mathrm{H}$ pyrazole-4-carbonitrile-5-diazonium chloride 3'. The second step involves the coupling off the 3 with active methylenes as acetylacetone and malononitrile, in pyridine from $0{ }^{\circ} \mathrm{C}$ to $5{ }^{\circ} \mathrm{C}$ to yield the corresponding hydrazono intermediates $\mathrm{A}$ and B. During the third step, intramolecular cyclization by nucleophilic attack of nitrogen occurs in the pyrazole ring on the acetyl and cyano groups to form intermediates A' and B', followed by proton abstraction to generate intermediate adducts A" and B". Finally, aromatic-driven 1, 4-dehydration in A" forms 4; and 1, 5-hydrogen migration in B" yields 5.

Fusion of the compound 3 with acetic anhydride under reflux for 15 minutes furnished the corresponding 1-acetyl-5amino-3-(4-chlorophenylamino)-1 $H$-pyrazole-4-carbonitrile 6 (Figure 7). The structures of the compound 6 were established on the basis of spectral data. The IR spectrum showed the absence of NH band and display band at $v 1703$ $\mathrm{cm}^{-1}$ due to carbonyl group, while the ${ }^{1} \mathrm{H}-\mathrm{NMR}$ spectra showed characteristic signal at $\delta 2.56 \mathrm{ppm}$ due to methyl protons attached to carbonyl group $\left(\mathrm{CH}_{3}-\mathrm{CO}\right)$. The structure of the isolated product 6 was supported by their direct infusion mass spectrometry (DIMS) result, which showed molecular ion corresponding to the molecular formula. The DIMS spectrum of 9 showed a molecular ion at $m / z=275.65$, which corresponding to a molecular formula $\mathrm{C}_{12} \mathrm{H}_{10} \mathrm{ClN}_{5} \mathrm{O}$ $\mathrm{M}^{+}$requires 275.69.<smiles>CC(=O)OC(=O)C(C)(C)OC(C)=O</smiles>

Figure 7. Synthesis of 1-acetyl-1H-pyrazole 6.

\subsection{Antibacterial, Antifungal Evaluations and Cytotoxicity Assay}

The antibacterial and antifungal activities results are listed in Table 3. The results for the pyrazolo $[5,1-c][1,2,4]$ triazine 5 showed moderate against tested bacteria and fungi. It was also demonstrated in this study that the compound 6 exhibited good antibacterial and antifungal activities.

Table 3. Inhibition zone (mean diameter of inhibition in $\mathrm{mm}$ ) as a criterion of antibacterial and antifungal activities of the synthesized compounds.

\begin{tabular}{|c|c|c|c|c|c|}
\hline \multirow{3}{*}{ Compound } & \multicolumn{5}{|l|}{ Inhibition zone $(\mathrm{mm})^{\mathrm{c}}$} \\
\hline & \multicolumn{3}{|l|}{ Antibacterial evaluation } & \multicolumn{2}{|c|}{ Antifungal evaluation } \\
\hline & Staphylococcus aureus $\mathbf{S 2 7 6}$ & $\begin{array}{l}\text { Staphylococcus } \\
\text { eperdermidis } S 273\end{array}$ & $\begin{array}{l}\text { Pseudomonas } \\
\text { aeruginosa } 15442\end{array}$ & $\begin{array}{l}\text { Aspergillusniger } \\
\text { UРМС } 393\end{array}$ & $\begin{array}{l}\text { Aspergillusbrasiliensis } \\
\text { ATCC16404 }\end{array}$ \\
\hline 5 & $7 \pm 0.57$ & $9 \pm 0.57$ & $8 \pm 0.55$ & $9 \pm 0.58$ & $7 \pm 0.58$ \\
\hline 6 & $10 \pm 0.58$ & $10 \pm 0.58$ & $11 \pm 0.58$ & $10 \pm 0.58$ & $10 \pm 0.58$ \\
\hline a Streptomycin & 20 & 23 & 27 & - & - \\
\hline bystatin & - & - & - & 20 & 23 \\
\hline
\end{tabular}

${ }^{\text {a }}$ Setreptomycin as reference drug for bacteria.

${ }^{b}$ Nystatin as reference drug for fungi.

${ }^{c}$ Values are mean inhibition zone $(\mathrm{mm}) \pm \mathrm{S}$. D of results done in triplicate.

$6 \mathrm{~mm}$ is the diameter of the disc

Cytotoxicity results of two tested compounds are summarized in Table 4. The $\mathrm{CC}_{50}$ value was graphically obtained by plotting the percentage growth inhibition against the corresponding different concentrations of the test compound used. The $\mathrm{CC}_{50}$ values for compounds 8 and 9 have $\mathrm{CC}_{50}$ value of more than $30 \mu \mathrm{g} / \mathrm{ml}$. According to Chandrashekar et al [21], $\mathrm{CC}_{50}$ value of more than $20 \mu \mathrm{g} / \mathrm{ml}$ can be considered as non cytotoxic.

Table 4. Cytotoxicity (CC 50 ) of two compounds against Human MCF-7 cells.

\begin{tabular}{ll}
\hline Compounds & CC50 value $(\boldsymbol{\mu g} / \mathbf{m l})$ \\
\hline 5 & $>30$ \\
6 & $>30$ \\
\hline
\end{tabular}

\section{Conclusions}

We could successfully synthesized new pyrazolo $[5,1-c]$ $[1,2,4]$ triazines from 5-aminopyrazole 3 . In this paper, we synthesized new pyrazolo $[5,1-c][1,2,4]$ triazines 4,5 by the reaction of 5 -aminopyrazole 3 with respective malononitrile, and acetyl acetone. Also, 5-aminopyrazole 3 reacted with acetic anhydride gave the corresponding 1acetyl-1H-pyrazole 6 . All procedures for the synthesis of these compounds are very convenient due to the simple procedures, mild conditions, and moderate to high yields. Another advantage is that 5-aminopyrazole 3 was of the same 
starting material used for the preparation of all those compounds. Some of the prepared compounds shown unpromising antibacterial, antifungal activities and cytotoxicty.

\section{Acknowledgments}

The authors thank the scholarship from the Libyan government to WMA is greatly appreciated.

\section{References}

[1] M. Mojzych; A. Rykowski, J. Wierzchowski, Pyrazolo [4, 3-e] $[1,2,4]$ triazines: Purine analogues with electronic absorption in the visible region, Molecules, 10 (2005) 1298-1306.

[2] W. B. Parker, J. A. Secrist, W. R. Waud, Purine nucleoside antimetabolites in development for the treatment of cancer. Curr. Op. Invest. Drugs 5 (2004) 592-596.

[3] B. Zacharie, T. P. Connolly, R. Rej, G. Attardo, C. L. Penney, A short synthesis of 4-substituted 1-(hydroxyalkyl)-1Hpyrazolo $[3,4-d]$ pyrimidines, Tetrahedron, 52 (1996) 22712278.

[4] C. R. Petrie III, H. B. Cottam, P. A. McKernan, R. K. Robins, G. R Revankar. Synthesis and biological activity of 6azacadeguomycin and certain 3, 4, 6-trisubstituted pyrazolo $[3,4-d]$ pyrimidine ribonucleosides, J. Med. Chem. 28 (1985) 1010-1016.

[5] G. A Bhat, J. G. Montero, R. P. Panzica, L. L. Worting, L. B. Towsend, pyrazolopyrimidine nucleosides. 12. Synthesis and biological activity of certain pyrazolo $[3,4-d]$-pyrimidine nucleosides related to adenosine. J. Med. Chem. 24 (1981) 1165-1172.

[6] M. A. Gouda, M. A. Berghot, A. I. Shoeib, A. M. Khalil, Synthesis and antimicrobial activity of new anthraquinone derivatives incorporating pyrazole moiety, Eur. J. Med. Chem. 45 (2010) 1843-1848.

[7] M. A. Gouda, A. I. Berghot, E. A. Ghada, A. M. Khalil, Synthesis and antimicrobial activities of some new thiazole and pyrazole derivatives based on 4, 5, 6, 7tetrahydrobenzothiophene moiety, Eur. J. Med. Chem. 45 (2010) 1338-1345.

[8] Wedad M. Al-Adiwish, M. I. M. Tahir, Siti-NoorAdnalizawati A., Siti Farah Hashim, Nazlina Ibrahim and W. A. Yaacob. 2013. Synthesis, Antibacterial Activity and Cytotoxicity of New Fused Pyrazolo $[1,5-a]$ pyrimidine and Pyrazolo [5, 1-c] [1, 2, 4] triazine Derivatives from New 5Aminopyrazoles. European Journal of Medicinal Chemistry 64: 464-476.
[9] M. A. Elnagdi, M. R. H. Elmoghayer, G. H. Elgemeie, Chemistry of pyrazolopyrimidines, Adv. Heterocyclic Chem. 41 (1987) 320-367. J. D. Anderson, H. B. Cottam, S. B. Larson, L. D. Nord, G. R. Revankar, R. K. Robins, Synthesis of certain pyrazolo [3, 4-d] pyrimidin-3-one nucleosides, J. Heterocyclic Chem. 27 (1990) 439-453.

[10] J. L. Avila, M. A. Polegre, A. R. Avila, K. Robins, Action of pyrazolopyrimidine derivatives on american Leiishmania SPP Promastigotes, Comp. Biochem. Physiol. 83C (1986) 285-289.

[11] J. Salimon, N. Salih, Synthesis, characterization and biological activity of some new 1, 2, 4-triazine derivatives. Int. J. Pharm. Tech. Res. 2 (2010) 1041-1045.

[12] M. Mariusz, Antiviral activity evaluation of pyrazolo [4, 3-e ] $[1,2,4]$ triazines, J. Chem. Soc. Pak. 33 (2011).

[13] M. Yokoyama, H. Togo, S. Kondo, Synthesis of heterocycles from ketene dithioacetals, Sulfur Rep. 10 (1990) 23-47.

[14] M. A. Zaharan, A. M. Sh. El-Sharief, M. S. A. El-Gaby, Y. A. Ammar, U. H. El-Said, Some reactions with ketene dithioacetals Part I: Synthesis of antimicrobial pyrazolo [1, 5a] pyrimidines via the reaction of ketene dithioacetals and 5aminopyrazoles, Il Farmaco 56 (2001) 277-283.

[15] Clinical and Laboratory Standards Institute, Performance Standards for Antimicrobial Disk Susceptibility Test. Approved Standard, ninth ed., CLSI, Wayne, PA, USA, 2006.

[16] Mosmann T. Rapid Colorimetric Assay for Cellular Growth and Survival: Application to Proliferation and Cytotoxicity Assays. Journal of Immunology Methods 1983; 65: 55-63.

[17] F. H. Allen, O. Kennard, D. G. Watson, L. Brammer, A. G. Orpen, R. $J$. Taylor, Table of bond lengths determined by Xray and neutron diffraction. Part 1 . Bond lengths in organic compounds, Chem. Soc. Perkin Trans. 2. (1987), S1 \pm S19.

[18] CCDC 1033262 contains the supplementary crystallographic data for this paper. These data can be obtained free of charge via www.ccdc.cam.ac.uk/conts/retrieving.html (or from the CCDC, 12 Union Road, Cambridge CB2 1EZ, UK, fax: +44 1223 336033, e-mail: deposit@ccdc.cam.ac.uk).

[19] M. A. Gouda, M. A. Berghot, A. I. Shoeib, A. M. Khalil, Synthesis and antimicrobial activity of new anthraquinone derivatives incorporating pyrazole moiety, Eur. J. Med. Chem. 45 (2010) 1843-1848.

[20] M. A. Gouda, A. I. Berghot, E. A. Ghada, A. M. Khalil, Synthesis and antimicrobial activities of some new thiazole and pyrazole derivatives based on 4, 5, 6, 7tetrahydrobenzothiophene moiety, Eur. J. Med. Chem. 45 (2010) 1338-1345.

[21] Chandrashekar, G. J., Gopal, M. And Byregowda, S. M. 2011. Cytotoxic activity of Tragia involucrate. Linn. Extract. American-Eurasian Journal of Toxicological Sciences. 3 (2): 6769. 